persons suffering from heart diseases may receive early treatment. These diseases produce their worst effects during the most productive period (generally after the age of forty), and it is calculated that 100 million pesos represents the social cost of early death and forced retirement of such persons. Social assistance should be given not only to the actual patients but also to needy perstons who are burdened with their maintenance. As regards State action, the Argentine Government has provided for a compulsory State examination, and legal restrictions have been made on the work done by persons suffering from cardio-vascular diseases.

\section{Endocrinology in Montevideo}

The June issue of the Boletin de la Oficina Sanitaria Panamericana contains an interesting account of the Institute of Endocrinology at Montevideo, which was founded in 1937 and serves as a teaching, preventive, therapeutical and research centre. It is under the direction of Dr. J. C. Mussio Fournier, professor of endocrinology in the Montevideo School of Medicine, who was recently president of the Second Panamerican Congress of Endocrinology held at Montevideo. The Institute possesses a staff of visiting nurses who regularly inspect the schools at Montevideo, and under the guidance of a school doctor select for observation and treatment children suffering from endocrine disorders. A hospital is attached to the Institute, consisting of three wards, for men, women and surgical cases respectively. The majority of the patients are suffering from endocrine diseases, but other complaints in adults and children are also treated.

\section{A 1,000-kw. Wind-driven Electric Generator}

A PLANT which is said to represent the first serious attempt to study the generation of electricity by wind power on such a scale that its practical and economic possibilities may be judged, is described in Engineering of July 31. The plant consists of a twobladed wind-turbine and $\mathrm{a} 1,000-\mathrm{kw}$. alternator mounted on a pintle girder on the top of a lattice steel tower $110 \mathrm{ft}$. high, and it has been erected on the summit of a 2,000-ft. mountain known as Grandpa's Knob, near Rutland, in the State of Vermont. Though in a sense the plant is experimental, the current generated will be used by the Central Vermont Public Service Corporation. It has been estimated that it will be possible to use the power of the wind for 4,000 hours a year. The blades of the turbine are each $65 \mathrm{ft}$. long and $11 \mathrm{ft}$. wide and weigh $15,300 \mathrm{lb}$. The circle described by the ends of the blades is $175 \mathrm{ft}$. in diameter and at $28.7 \mathrm{r} . \mathrm{p} . \mathrm{m}$. the tip speed is $15.785 \mathrm{ft}$. per minute. The alternator is driven through gearing and generates three-phase current at 60 cycles and 2,300 volts. The designer of the wind turbine, Mr. P. C. Putnam, has had the assistance of others, and model tests of his turbine were made in the wind tunnel of Stanford University. There are many interesting features in the plant, and so that an exhaustive study of wind variations can be made an anemometer tower $180 \mathrm{ft}$. high has been erected close by and fitted with three types of anemometers.

\section{Recent Earthquakes}

The United States Coast and Geodetic Survey, in co-operation with Science Service and the Jesuit Seismological Association, has found the provisional epicentre of the earthquake of June 29, which occurred at about $6 \mathrm{~h} .26 \cdot 4 \mathrm{~m}$. U.T. From instrumental reports from eleven observatories, the epicentre turned out to be near latitude $34 \cdot 5^{\circ} \mathrm{S}$., longitude $70.5^{\circ} \mathrm{W}$., which is south-east of Rancagua in Chile. This is definitely in a seismic district, and the depth of focus of slightly greater than normal is not without precedent near the Andes.

ON August 6 a severe earthquake began recording at $23 \mathrm{~h} .49 \mathrm{~m}$. 04s. U.T. A maximum ground amplitude of $800 \mu$ was recorded at Kew on the vertical component seismograph on August 7 at ca. 00h. 25m. U.T. According to a tentative interpretation, the first impulse is a $P$ wave, the $S$ wave following at $23 \mathrm{~h}$. 59m. 15s. U.T on August 6, and according to the tables in use at Kew the epicentral distance would then be approximately $9,000 \mathrm{~km}$.

\section{Announcements}

Prof. James Gray, professor of zoology in the University of Cambridge, and Prof. F. L. Engledow, Drapers professor of agriculture in the University of Cambridge, have been appointed members of the Agricultural Research Council in succession to Sir Merrik Burrell and Prof. D. M. S. Watson, whose terms of office as members of the Council have expired.

President Roosevelt has appointed the follow ing committee to examine the whole field of synthetic rubber production and to report as quickly as possible : Mr. Bernard Baruch (chairman), who was the head of the War Industries Board during 1917-18; Dr. James Conant, president of Harvard University, and Dr. Karl Compton, president of the Massachusetts Institute of Technology.

A PANEL has been set up to inquire into the possibility of improving the ventilation of tanks either by use of refrigeration or by air conditioning. It is constituted as follows: Mr. S. A. Wood, senior scientific officer, Scientific Research Department, Ministry of Supply; Dr. Dorey, chief engineer surveyor, Lloyd's Register ; and Dr. Ezer Griffiths, principal scientific officer, Physics Department, National Physical Laboratory.

THE Honorary Medal of the Royal College of Surgeons of England has been awarded to Lord Nuffield in recognition of his conspicuous service in assisting the improvement of natural knowledge and of the healing art and of his many liberal acts and distinguished labours inspired by the desire to advance the science and practice of medicine and surgery. The Honorary Medal was instituted a hundred and forty years ago, and this is the nineteenth occasion on which it has been awarded.

THE following appointments, promotions and transfers in the Colonial Service have recently been made: D. E. MacGregor, veterinary officer, Nigeria ; F. Davidson, rubber production officer, Gold Coast; C. W. Lynn (agricultural superintendent), senior agricultural superintendent, Gold Coast; J. D. Kennedy (senior assistant conservator of forests), conservator of forests, Nigeria; C. R. Petty (senior surveyor), deputy director of surveys, Gold Coast; H. R. Binns (veterinary research officer), senior veterinary research officer, Palestine. 